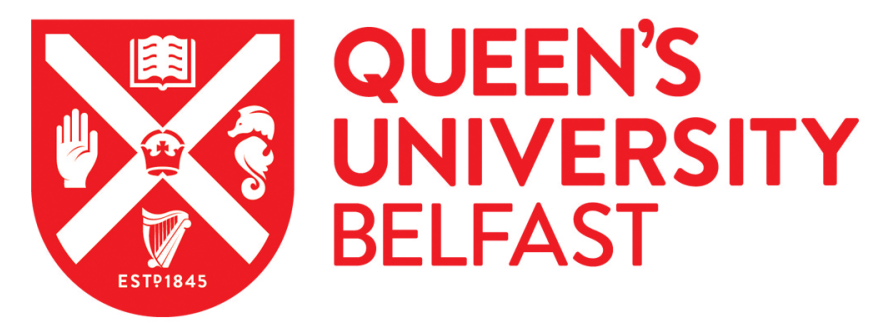

\title{
Health care students experience of using digital technology in patient care: a scoping review of the literature
}

Brown Wilson, C., Slade, C., Wong, W. Y. A., \& Peacock, A. (2020). Health care students experience of using digital technology in patient care: a scoping review of the literature. Nurse Education Today, [104580]. https://doi.org/10.1016/j.nedt.2020.104580

Published in:

Nurse Education Today

Document Version:

Peer reviewed version

Queen's University Belfast - Research Portal:

Link to publication record in Queen's University Belfast Research Portal

Publisher rights

(c) 2020 Elsevier Ltd. All rights reserved.

This manuscript version is made available under the CC-BY-NC-ND 4.0 license http://creativecommons.org/licenses/by-nc-nd/4.0/,which permits distribution and reproduction for non-commercial purposes, provided the author and source are cited.

\section{General rights}

Copyright for the publications made accessible via the Queen's University Belfast Research Portal is retained by the author(s) and / or other copyright owners and it is a condition of accessing these publications that users recognise and abide by the legal requirements associated with these rights.

Take down policy

The Research Portal is Queen's institutional repository that provides access to Queen's research output. Every effort has been made to ensure that content in the Research Portal does not infringe any person's rights, or applicable UK laws. If you discover content in the Research Portal that you believe breaches copyright or violates any law, please contact openaccess@qub.ac.uk. 
Title: Health care students experience of using digital technology in patient care: a scoping review of the literature

Authors:

Christine Brown Wilson, Christine Slade, Wai Yee Amy Wong, Ann Peacock.

\section{Abstract}

Objectives: To explore how undergraduate health care students use digital technology to deliver patient care during their clinical placements.

Design: A scoping review of primary research was conducted using the extended PRISMA guidelines.

Data sources: A subject specialist librarian assisted in searching for the academic literature in four electronic databases: CINAHL, PubMed, Scopus and ERIC.

Review methods: Four reviewers, working in pairs, independently reviewed a total of 332 potentially relevant articles according to set inclusion and exclusion criteria. Then, all included papers underwent an independent quality review by two reviewers.

Results: Seven studies involving medical or nursing/midwifery students were included in the review. Three studies evaluated the use of mobile learning devices in patient care with four studies evaluating the use of digital systems in practice. Due to the heterogeneity of studies, which used differing digital systems and instruments, the researchers decided the most suitable method of analysis was a narrative review. The results are explained using four key themes: student learning needs when using technology in practice; access to technology in placements; perceptions of using technology in placements; and impact of technology on patient care.

Conclusion: The use of digital systems in clinical settings creates challenges and benefits to student learning in delivering patient care. When students are prepared and facilitated to use digital systems, a sense of confidence and belonging to the team is fostered. Lack of availability and access to these systems, however, may impede students' ability to be involved in all aspects of patient care. Limitations of the current review included the relatively low quality of the educational research being conducted in this field of research. Further quality research is needed to explore how students in the health care professions are supported in digital environments and how higher education institutions are adapting their curricula to meet the digital learning needs of health care students. 


\section{Highlights}

- Digitalisation of health care has become a widespread practice

- Preparation and support are essential for using digital systems on placements

- Students feel a sense of belonging when provided with access to patient information

- Further support is required for students to integrate the use of technology during the patient encounter 


\section{Introduction}

The use of technology in health care has become a widespread practice which enables patients to be more involved in their own care. Such technology includes the use of wearable devices, smartphone apps, telemedicine and electronic health records (EHRs). More recently digital hospitals have integrated electronic medical records with clinical devices and workflows that provide real time information to improve patient outcomes (Queensland Audit Office, 2018). With the increasing digitalisation of health care, health professionals will require support in developing capability to use these digital systems (Topol, 2019). To this end, Health Education England (HEE) and the Royal College of Nursing (RCN) adapted the Jisc (Joint Information Systems Committee) Digital Capability Framework (2015) to facilitate a shared understanding of digital capabilities across the health care sector (National Health Service (NHS) (RCN, 2017). The impact of technology on patient relationships places additional demands on nurses and midwives' ICT skills in practice (While and Dewsbury, 2011). For nursing, a cultural shift is required to embrace a 'nursing is knowing' model rather than 'nursing is doing' (Clark, 2007, p.110). This shift emphasises the transition between nursing as activities and tasks to enabling clinical knowledge and judgement through the use of digital tools and systems to improve care (Clark, 2007; RCN, 2017). Furthermore, industry is now demanding that graduates are better prepared to use eMedical or eHealth records in patient care (Fetter, 2009). Implications for universities include ensuring that their students embrace this professional cultural shift and are confident in digital clinical skills whilst on placements.

The Jisc Digital Capability Framework (2015) presents a thought-provoking conception of the digital skills students will need as future leaders in digital work environments. The expectations outlined in this Framework are broader than ICT proficiency and relate to: digital creation, problem solving and innovation; information, data and media literacies; digital learning and development; digital communication, collaboration and participation; and encompassed in digital identity and wellbeing (Jisc 2019).

Nursing and midwifery students undertake placements as high impact learning experiences. Extensive clinical experiences and supervision promote student learning which may occur in digital healthcare environments as part of their academic 
programs. Many students, however, receive minimal or no training in such systems while in university study (Milano et al. 2014), resulting in students feeling under prepared for working with digital systems (Baillie et al. 2012). At a curriculum level Bembridge et al. (2011) suggests the inclusion of early and progressive opportunities for students to gain ICT competencies, particularly in clinical applications and practice essentials, so students could make an explicit connection 'between ICT competence and improved patient outcomes' (p. 251). Students need to acquire and practise linking digital skills and knowledge to patient care. In the researchers' teaching context students recognise a disconnection between the digital systems used in hospitals and the university curriculum. This situation prompted the researchers to undertake this scoping review.

The purpose of this review was to collate and interrogate current scholarly literature that informs the preparation process for nursing and midwifery students to undertake clinical placements and to ultimately work in digital health care environments. Therefore, the following research question was posed: 'How is digital technology used by health care students when delivering patient care during clinical placements?'

\section{Methods}

Scoping reviews are most appropriate when the existing literature is limited but with emerging evidence on a topic (Peters et al. 2015; Tricco et al. 2018). The researchers used the five steps recommended by Arksey and O'Malley (2005) to structure the review process: identifying the research question; identifying relevant studies; study selection; charting the data; and, collating, summarising and reporting the results. The results of this scoping review are reported using the updated PRISMA guidelines for scoping reviews (Tricco et al. 2018).

\section{Search Strategy}

On 15 April 2019 we conducted a systematic search on four databases: CINAHL, PubMed, Scopus and ERIC using the search terms alongside Boolean operators (AND/OR) presented in Table 1. A pilot search including the term 'student' retrieved 684 results. This search was assessed by one member of the research team and found to have a large amount of irrelevant papers, so the term 'student' was excluded in subsequent searches. 


\section{Table 1 Search terms used in the final search about here}

\section{Study selection and data extraction}

The team developed the following inclusion criteria 1) written in English, 2) undergraduate pre-registration health care students, 3) using technology for direct patient care, and 4) in practice placements. The final search retrieved 332 papers with 185 results in CINAHL,120 in Scopus and 27 in PubMed and no results for ERIC. After duplicates were removed, we had 277 potentially relevant papers. The researchers worked in pairs to independently assess all papers for inclusion or exclusion. If there was a disagreement between researchers in a pair, the other pair of researchers was asked to make a decision.

\section{Figure 1 PRISMA diagram about here}

Two hundred and fifty-nine papers were excluded based on the title/abstract screen with 18 papers retrieved for full paper review. References were searched from relevant papers retrieving an additional paper (Figure 1). A total of 19 papers went through the full paper review. Twelve papers were excluded for one of the following reasons: the paper focused exclusively on assessment in practice; did not provide data on the use of an electronic system in placements, or, did not provide data on how the system was used for patient care. As a result, seven papers were included in the scoping review (Figure 1).

Data were extracted and charted using a predefined data extraction table (Table 2). The review team worked in pairs to ensure key data were extracted and themes identified across the papers.

\section{Table 2 Data extracted from the reviewed studies about here}

\section{Quality assessment}

Seven articles were agreed for inclusion and reviewed for quality. Two authors (CBW and $A P$ ) undertook this blind review independently using the Critical Appraisal Skills Programme (CASP) checklists (available: https://casp-uk.net/casp-tools-checklists/) 
and MMAT for mixed methods studies (Hong et al. 2018). Of the seven studies included, one was a Randomised Control Trial (RCT) (Wack et al. 2015), five were mixed-methods (Baillie et al. 2013; Brooke-Read et al. 2012; Davies et al. 2012; Johansson et al. 2013; Rouf et al. 2008) and one was a qualitative study (Algeria et al. 2014). No studies were excluded based on the quality review.

Only one RCT study was available for this scoping review. Wack et al. (2015) recruited 35 final-year medical students across three clinical rotations to evaluate the impact of the use of Computerized Provider Order Entry (CPOE) on bedside training. Blinding was not appropriate although it was not clear how randomisation occurred. Appropriate data analysis was undertaken including testing for inter-rater reliability. Modelling was also undertaken using ANOVA with the most parsimonious model to explain the results. Therefore, this study was identified as a moderate quality study.

The quality of the five mixed-methods studies were varied, ranging from high to low quality. The study conducted by Davies et al. (2012) employed a convergent design where qualitative and quantitative findings were used to explore the issue of interest. Whereas the studies conducted by Baillie et al. (2013) and Johansson et al. (2013) employed an explanatory sequential design where the purpose of the qualitative focus groups, that followed the quantitative survey, was to add further depth to the results of the survey. Rouf et al. (2008) employed a sequential exploratory study design where the researchers applied the findings from the qualitative focus groups to develop a survey instrument. Similarly, this study design was also employed by Brooke-Read et al. (2012) where the researchers developed a quantitative questionnaire based on a literature review, followed by a focus group in which the participants were self-selected from completing the questionnaire.

The quantitative component of each mixed-methods study included a non-validated survey derived either from a focus group (Rouf et al. 2008) or the literature (Bailie et al. 2012; Brooke-Read et al. 2012; Davies et al. 2012). All the studies indicated they had piloted the questionnaire first and then excluded this sample from the main study. This is an appropriate methodological approach where existing survey instruments do not exist. However, no studies provided any tests of validity for their instruments. Johansson et al. (2013) was the only study that ensured the generalisability of their 
questionnaire with a sample that was randomised, although the researchers did not explain how they developed their questionnaire. All the other studies used a convenience sample of students in a placement with exposure to the technology of interest. However, all papers analysed their quantitative data using descriptive statistics, which was appropriate to the sample sizes.

Davies et al. (2012) was the only mixed-methods study that described a clear theoretical direction for the qualitative component using a grounded theory approach to explore the themes that emerged from the initial student survey. The analysis of both data sets converged to develop an educational model to understand the issues being explored, which led this study to be rated as high quality.

Unlike Davies et al. (2012), Bailie et al. (2012), Brooke-Read et al. (2012) and Johansson et al. (2013) did not use a theoretical approach to their qualitative component, but they did adopt a validated approach to their qualitative data analysis. Baillie et al. (2012) and Johansson et al. (2013) clearly linked the quantitative and qualitative data sets in the analysis and their studies were of moderate quality. In contrast, Brook-Read et al. (2012) reported their quantitative and qualitative results independently to each other and, therefore, their study was of low quality. The study conducted by Rouf et al. (2008) was also considered to be of low quality as it failed to report appropriately on qualitative data collection and analysis that led to the development of the survey instrument.

Algeria et al. (2014) undertook a qualitative study which comprised focus groups with a purposeful sample of 15 students. All focus groups were audiotaped and transcribed with two researchers undertaking a thematic analysis to a pre-defined framework based on the literature. However, the data analysis process was not clearly defined and issues of rigour were not discussed. The quotes used to map the themes were not attributed to specific students, which limited the credibility of the findings rendering the study as low quality.

The majority of studies used mixed-methods to answer the research questions, with only one study (Davies et al. 2012) considered high quality. Only one moderate quality RCT (Wack et al. 2015) was located, which revealed the difficulty of undertaking this 
style of research in education. Nevertheless, all the studies in this scoping review were undertaken between 2008 and 2015 when technology in health care was emerging. Analysis of these papers was limited by the heterogeneity of the studies using different cohorts of students, investigating a range of technologies and the use of non-validated questionnaires. Therefore, a narrative analysis is undertaken to discuss the results.

\section{Results}

Seven studies are included in this review: four studies included medical students (Algeria et al. 2014; Davies et al. 2012; Rouf et al. 2008; Wack et al. 2015) with the remainder including nursing and/or midwifery students (Baillie et al. 2013; BrookeRead et al. 2012; Johansson et al. 2013). Most studies used convenience sampling with between 35 and 60 students on a specific placement. Only one study surveying an entire cohort of 350 student nurses and midwives with 215 completed questionnaires received (participation rate=61\%) (Baillie et al., 2013). The overall participation rate (considering the highest in each study) was over $50 \%$ in all the studies under this review.

Four studies considered the use of digital health systems which were already in practice. Three studies were related to electronic health records (EHRs) (Baillie et al. 2013; Brooke- Read et al. 2012; Rouf et al. 2008) with one study exploring the use of a computerised prescribing system (Wack et al. 2015). The remaining three studies considered the use of mobile technology such as tablet computers (Algeria et al. 2014) or personal digital assistants (PDAs) to access either patient records or information that could be used directly with patients during an episode of care (Davies et al. 2012; Johansson et al. 2013).

Four key themes emerged from these studies: students learning needs when using technology in the practice environment; access to technology when on placements; perceptions of using technology on placements; and impact of technology on patient care.

\section{Students learning needs when using technology in the practice environment}

It is critical to prepare and guide health care students to use digital health systems in the practice environment appropriately to achieve expected learning outcomes (Baillie 
et al. 2013; Rouf et al. 2008; Wack et al. 2015). For example, 50\% of nursing/midwifery students in Baillie et al.'s (2013) study identified that lack of training on the EHR system was a barrier to its use and $58 \%$ of the same sample indicated that they felt illprepared for record keeping using EHRs. Similarly, the medical students who attempted to use a computerised prescribing system struggled with being able to use it appropriately for their learning of prescription skills (Wack et al. 2015). In the focus group discussion, some students indicated that a barrier of using mobile technology was due to their own discomfort in using technology (Algeria et al. 2014; Davies et al. 2012).

In the studies with medical students (Rouf et al. 2008; Wack et al. 2015), the students found it easier to locate information on the EHRs including clinical guidelines and medication interactions. They were also able to receive feedback from their clinical supervisors which accommodated their learning needs.

\section{Access to technology when on placements}

The nursing/midwifery students in Baillie et al.'s (2013) study were only able to access the EHR system under direct supervision. This impacted the students being able to document patient care electronically and in a timely manner, as they were required to obtain verification from their mentors or staff with verification authority. This delayed the documentation process compared to the paper notes when the staff were busy or did not understand the electronic verification process. In addition, the medical students using a computerised prescribing system struggled with finding a terminal on the ward when it was required (Wack et al. 2015). Similarly, the midwifery students had to leave the woman in labour to access the EHR on a terminal external to the room (BrookeRead et al. 2012). Overall, nursing/midwifery students identified using EHRs as a positive learning experience when their practice supervisors ensured that they had access to the patients' EHRs and were able to document the care they provided (Baillie et al. 2013).

In the case of portable devices, students across the studies raised concerns about functionality, portability and potential loss of the devices (Algeria et al. 2014; Davies et al. 2012). However, in longitudinal studies, this concern reduced over time and the 
focus became more on the learning opportunities that arose by using the portable devices (Algeria et al. 2014).

\section{Perceptions of using technology on placements}

Students identified that clinical staff might think they were using their phone for personal reasons whilst on placements (Davies et al. 2012) or that clinical supervisors might view a student using a PDA is an indication that the student lacked knowledge or would make the patient feel uncomfortable (Johansson et al. 2013). Conversely, students felt the immediacy of accessing information using PDAs, which provided them with confidence as they delivered patient care (Johansson et al. 2013). They also felt part of the team when they had access to the same patient information using PDAs (Johansson et al. 2013). Similarly, medical students using a computerised prescribing system scored better in involvement in patient care, which suggested an increased sense of belonging to the medical team (Wack et al. 2015). Student nurses and midwives also felt more prepared for becoming registered nurses and midwives when using the EHRs (Baillie et al. 2013).

\section{Impact of technology on patient care}

Nursing students using PDAs found it was easier to access accurate information which was essential for them to undertake the required tasks satisfactorily (Johansson et al. 2013). In the same study $50 \%$ of the respondents who indicated they used PDAs at the bedside also found it beneficial in providing information for patients and/or their relatives rather than leaving the patient to retrieve necessary information (Johansson et al. 2013).

In contrast, midwifery students who accessed the EHRs in the clinical environment identified how the lack of sufficient mobile devices hindered their ability to make contemporaneous notes whilst caring for the woman in labour (Brooke-Read et al. 2012). Medical students across studies found PDAs and other mobile devices of value in learning but rarely used mobile devices as part of their patient encounter (Algeria et al. 2014; Davies et al. 2012). Some of the medical students stated that they believed the use of technology would harm the patient relationship (Davies et al. 2012).

The use of EHRs was considered a positive way to access patient information, as well 
as improving communication between professionals and making patient notes easier to read (Brooke-Read et al. 2012; Rouf et al. 2008). In Rouf et al.'s (2008) study, 64\% of medical students were satisfied with the doctor-patient communication whilst using the EHRs. However, $24 \%$ of medical students indicated that they spent less time talking to the patients and $45 \%$ spent less time looking at the patients, with only $24 \%$ identifying the EHRs helped with patient rapport (Rouf et al. 2008). Similarly, student midwives in Brooke-Read et al.'s (2012) study felt that the use of technology was incongruous with normality in childbirth, with computers taking their attention from the woman. Alternatively, Wack et al.'s (2015) study found no difference in the satisfaction with patient care between students prescribing on the computerised system and those using the usual system.

Overall when health care students were exposed to digital systems in practice, they had a more positive attitude towards the use of technology, irrespective of the systems in place in different clinical settings (Baillie et al. 2013; Rouf et al. 2008; Wack et al. 2015).

\section{Discussion}

The findings of this scoping review of students' use of digital devices and/or systems in their placements provides us with insights into the enablers and barriers encountered. The findings also highlight potential student-focused implications for educators in developing new curricula and learning activities.

The use of digital systems in clinical settings has the potential to support student learning, enabling them to contribute to the delivery of quality patient care. This review, however, also identifies some key challenges for consideration to ensure appropriate student learning when using digital systems in practice. Students need to feel prepared for the use of digital systems in place, particularly the use of EHRs. The findings demonstrate the importance of building students' confidence in using digital systems prior to placements, thus easing their discomfort on placements (Algeria et al. 2014; Davies et al. 2012). Therefore, educators may need to explore how to provide students with prior experience of using digital systems such as an EHR before going into placements in a digital health care setting. This could be achieved through simulated opportunities using digital work stations similar to those used by students in practice. 
Whilst Elliot et al. (2011) developed an in-house simulated electronic health record system for medical students to record patient encounters within their academic environment, this was not linked to the world of practice and so had limited benefits.

Mobile learning devices used in practice to augment learning may be another way of preparing students to access digital systems in practice (Chase et al., 2018; Dearnley et al. 2008; Friedrichs et al. 2014). For example, the use of these devices could be extended to the academic environment supporting students to access information electronically in a simulated patient encounter. Such solutions may support health care students to develop confidence in finding resources, patient record keeping, documentation and bedside patient interactions. Whilst this scoping review demonstrates that nursing students developed confidence in using PDAs at the point of care to enhance the patient encounter (Johansson et al. 2013), this was not the case for all students. Therefore, further research is needed to explore effective strategies to integrate the use of technology into a patient encounter without compromising the relationship and rapport between the health care student and the person receiving care.

When students feel that they are well-prepared for using digital systems in practice, the exposure to technology in practice generally increased students' feelings of confidence in the patient encounter (Baillie et al. 2013). Unfortunately, this may be mitigated by the level of support from clinical supervisors in enabling students to engage with the system in real time for patient care episodes (Baillie et al. 2013). This suggests it is essential to upskill clinical staff in practice to feel confident with the digital systems not only in their own use but in supporting students. The importance of training and changing the culture in the clinical workforce such as breaking the attitudinal barriers is also highlighted in the report 'Every nurse an e-nurse: Insights from a consultation on the digital future of nursing' (RCN, 2019). As recommended in the Topol Review, educators must engage in ongoing learning with a reflective approach to equip themselves in preparing the health care workforce to deliver high quality patient care in a digital world (Topol, 2019). Further collaborations may also be necessary with health care organisations providing placements. For example, this scoping review suggests that students would have improved learning opportunities if 
they were given central access to the digital systems rather than being dependent on individual supervisors at the point of care.

Another potential benefit of using digital devices and/or systems to student learning in practice is the development of a sense of belonging to their team. The studies in this scoping review underlined that when students have the same access to patient information as the established team members, it engenders a sense of belonging to the wider team. A sense of belonging is a crucial enabler to facilitate nursing students to attain competence in practice (Levett Jones and Lathlean, 2009) and realise their potential (Van der Riet et al. 2018). However, there are two challenges: one is the availability of opportunities using digital systems during placements, and second, the wide range of digital systems used to manage patient care. These challenges pose a barrier in supporting students to engage with digital health care practice as access to digital systems in placements may not necessarily be at the point of care, for example, in the labour wards or community settings. In addition, the knowledge of using a digital system might not be transferable from one placement to another. This implies that students may need to learn a new digital system whenever they commence their placements with a different health care organisation.

Mobile devices play an essential role to facilitate immediate access to patients' digital records at the point of care and provide information to answer questions from the patients and their carers (Johansson et al. 2013). Whilst the findings from this review are promising, further work is required to understand how the development of digital literacy in health care students may support the use of mobile devices to enhance patient care.

\section{Limitations}

Although no time limit was placed on the search, there were very few papers that focused on how patient care was influenced by health care students using digital technology in placements. Many papers were prior to 2015 when the use of digital technology in health care was emerging. Student nurses/midwives and medical students were the only health care professions featured across this review and other health care groups may have differing experiences to those noted in this study. This scoping review was also limited by the heterogeneity of studies and a lack of validated 
questionnaires in this field of research, resulting in the challenge of comparing findings effectively across studies, which was not always possible. Further research is needed to explore how higher education institutions are adapting their curricula to meet the digital learning needs of health care students.

\section{Conclusion}

This review provides the state of research in this emerging field of health care professions education at a time when the focus on digital systems in health care is gathering momentum. The findings suggest that students need to be equipped to effectively manage the challenges encountered in their future digital workplace to enhance the quality of patient care delivered. Therefore, it is imperative that higher education institutions develop complementary curriculum to equip student nurses and midwives to not only use these digital systems but be future leaders in the digital workplace. 


\section{References}

Alegría, D.A.H., Boscardin, C., Poncelet, A., Mayfield, C., Wamsley, M., 2014. Using tablets to support self-regulated learning in a longitudinal integrated clerkship. Med Educ Online 19(1), 23638. doi: 10.3402/meo.v19.23638

Arksey, H., O'Malley, L., 2005. Scoping studies: Towards a methodological framework. International Journal of Social Research Methodology, 8(1), 19-32, doi: $10.1080 / 1364557032000119616$

Baillie, L., Chadwick, S., Mann, R., Brooke-Read, M., 2013. A survey of student nurses' and midwives' experiences of learning to use electronic health record systems in practice. Nurse Educ Pract, 13(5), 437-441. doi:10.1016/j.nepr.2012.10.003

Bembridge, E., Levett-Jones, T., Jeong, S.Y., 2011.The transferability of information and communication technology skills from university to the workplace: A qualitative descriptive study. Nurse Educ Today 31(3), 245-252. doi:10.1016/j.nedt.2010.10.020

Brooke-Read, M., Baillie, L., Mann, R., Chadwick, S., 2012. Electronic health records in maternity: The student experience. British Journal of Midwifery 20(6), 440-445. doi:10.12968/bjom.2012.20.6.440

Chase, T.J.G., Julius, A., Chandan, J.S., Powell, E., Hall, C.S., Phillips, B.L., . . . Fernando, B., 2018. Mobile learning in medicine: An evaluation of attitudes and behaviours of medical students. BMC Medical Education 18(1), 152. doi:10.1186/s12909-018-1264-5

Clark, J., 2007. The impact of ICT on health, healthcare and nursing in the next 20 years. In: Murry, P, Park, H.A., Erdley, W.S., Kim, J. (Eds), Nursing Informatics 2020: Towards Defining Our Own Future. IOS Press, Amsterdam, pp. 95-114. 
Davies, B.S., Rafique, J., Vincent, T.R., Fairclough, J., Packer, M.H., Vincent, R., Haq, I., 2012. Mobile Medical Education (MoMEd) - how mobile information resources contribute to learning for undergraduate clinical students - a mixed methods study. BMC Medical Education 12(1), 1. doi:10.1186/1472-6920-12-1

Dearnley, C., Haigh, J., Fairhall, J., 2008. Using mobile technologies for assessment and learning in practice settings: A case study. Nurse Educ Pract 8(3), 197-204. doi:10.1016/j.nepr.2007.07.003

Elliott, K., Judd, T., McColl, G., 2011. A student-centred electronic health record system for clinical education. Stud Health Technol Inform 168, 57-64. doi: 10.3233/978-1-60750-791-8-57

Fetter M.S., 2009. Personal health records: Protecting behavioral health consumers' rights. Issues in Mental Health Nursing 30(11), 720-722. doi:

$10.1080 / 01612840902722179$

Friederichs, H., Marschall, B., Weissenstein, A., 2014. Practicing evidence based medicine at the bedside: A randomized controlled pilot study in undergraduate medical students assessing the practicality of tablets, smartphones and computers in clinical life. BMC Med Inform Decis Mak 14(1), 113. doi:10.1186/s12911-014-0113-7

Hong, Q.N., Gonzalez-Reyes, A., Pluye, P., 2018. Improving the usefulness of a tool for appraising the quality of qualitative, quantitative and mixed methods studies, the Mixed Methods Appraisal Tool (MMAT). J Eval Clin Pract 24(3), 459-467. doi: 10.1111/jep.12884

Joint Information Systems Committee (Jisc), 2015. Developing students' digital literacy. Available: https://digitalcapability.jisc.ac.uk/what-is-digital-capability/

Joint Information Systems Committee (Jisc), 2019. Jisc digital capabilities framework: The six elements defined. Available:

http://repository.jisc.ac.uk/7278/1/BDCP-DC-Framework-Individual-6E-110319.pdf 
Johansson, P.E., Petersson, G.I., Nilsson, G.C., 2013. Nursing students' experience of using a personal digital assistant (PDA) in clinical practice - an intervention study. Nurse Educ Today 33(10), 1246-1251. doi:10.1016/j.nedt.2012.08.019.

Levett-Jones, T., Lathlean, J., Higgins, I., McMillan, M., 2009. Staff-student relationships and their impact on nursing students' belongingness and learning. $J$ Adv Nurs 65(2), 316-324. doi:10.1111/j.1365-2648.2008.04865.x

Milano, C.E., Hardman, J.A., Plesiu, A., Rdesinski, R., Biagioli, F., 2014. Simulated electronic health record (Sim-EHR) curriculum: Teaching EHR skills and use of the EHR for disease management and prevention. Acad Med 89(3), 399-403. doi:10.1097/ACM.0000000000000149

Peters, M.D.J., Godfrey, C.M., Khalil, H., Mclnerney, P., Parker, D., Soares, C.B., 2015. Guidance for conducting systematic scoping reviews. International Journal of Evidence-Based Healthcare 13(3),141-146. doi:10.1097/XEB.0000000000000050

Queensland Audit Office, 2018. Digitising public hospitals Report 10: 2018-19. Available: https://www.qao.qld.gov.au/sites/default/files/reports/digitising-publichospitals 0.pdf

Rouf, E., Chumley, H.S., Dobbie, A.E., 2008. Electronic health records in outpatient clinics: Perspectives of third year medical students. BMC Medical Education 8(1),13. doi:10.1186/1472-6920-8-13

Royal College of Nursing (RCN), 2017. Improving digital literacy. RCN publication code 006 129. Available: https://www.rcn.org.uk/professionaldevelopment/publications/pub-006129

Royal College of Nursing (RCN), 2019. Every nurse an e-nurse: Digital capabilities for 21st century nursing. Available: https://www.rcn.org.uk/clinicaltopics/ehealth/every-nurse-an-e-nurse 
Topol, E., 2019. The Topol Review. Preparing the healthcare workforce to deliver the digital future. NHS Health Education England. Available: https://topol.hee.nhs.uk/

Tricco, A.C., Lillie, E., Zarin, W., O'Brien, K.K., Colquhoun, H., Levac D., ... Straus, S.E., 2018. PRISMA extension for scoping reviews (PRISMA-ScR): Checklist and explanation. Annals of Internal Medicine 169(7), 467-473. doi:10.7326/M18-0850

Van der Riet, P., Levett-Jones, T., Courtney-Pratt, H., 2018. Nursing students' perceptions of a collaborative clinical placement model: A qualitative descriptive study. Nurse Educ Pract 30, 42-47. doi:10.1016/j.nepr.2018.02.007

Wack, M., Puymirat, E., Ranque, B., Georgin-Lavialle, S., Pierre, I., Tanguy, A., . . . Avillach, P., 2015. Evaluating the impact of computerized provider order entry on medical students training at bedside: A randomized controlled trial. PLoS One 10(9), e0138094. doi:10.1371/journal.pone.0138094

While, A., Dewsbury, G., 2011. Nursing and information and communication technology (ICT): A discussion of trends and future directions. Int. J. Nurs. Stud. 48(10), 1302-1310. doi:10.1016/j.ijnurstu.2011.02.020 
Figure 1 PRISMA diagram

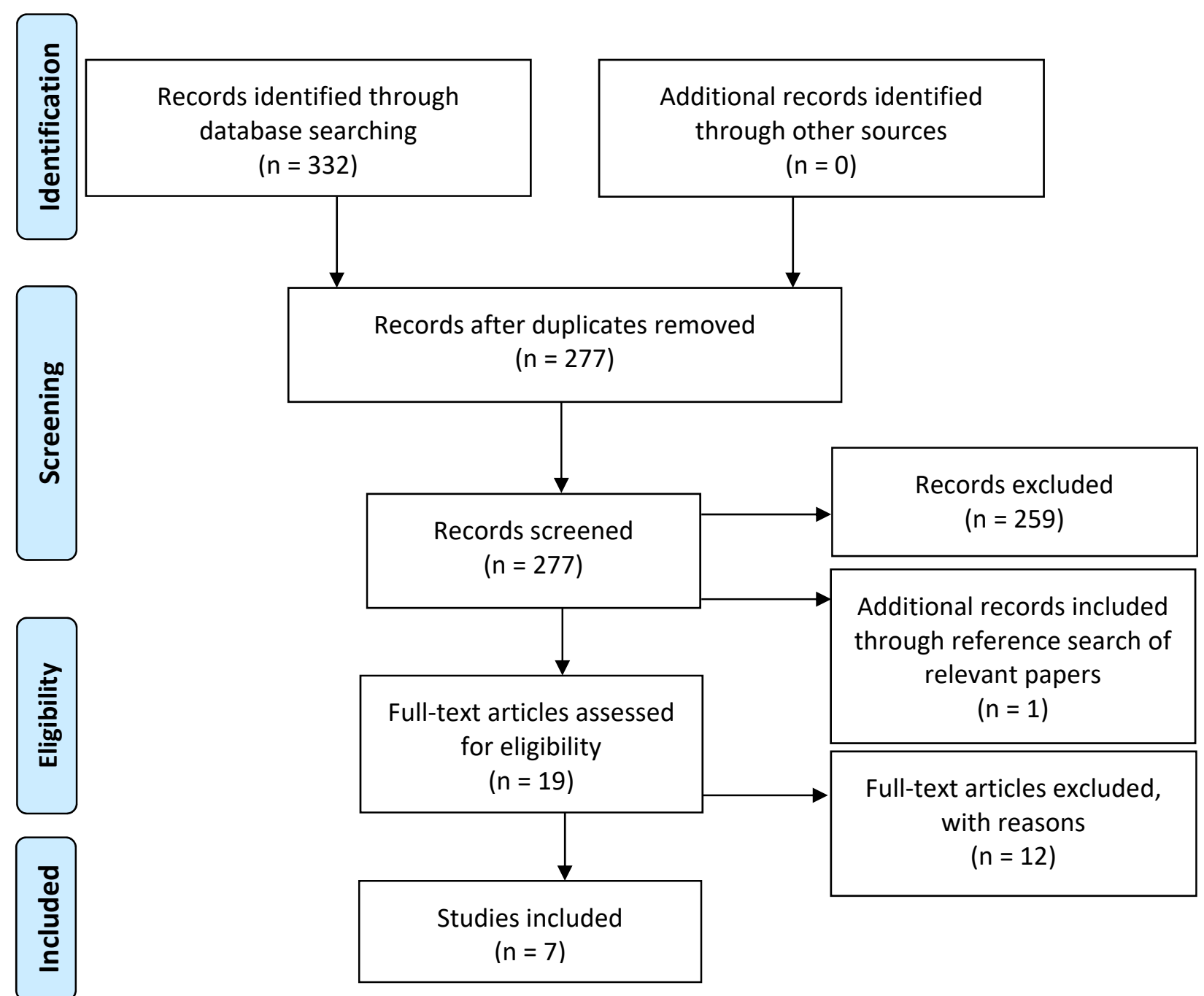


Table 1 Search terms used in the final search

\begin{tabular}{|l|l|}
\hline Term and variations & $\begin{array}{l}\text { Boolean } \\
\text { operators }\end{array}$ \\
\hline Placement* & AND \\
\hline $\begin{array}{l}\text { (MH "Electronic Health Records") OR (MH "Patient Record } \\
\text { Systems") OR (MH "Clinical Information Systems") OR (MH "Hospital } \\
\text { Information Systems") OR (MH "Clinical Laboratory Information } \\
\text { Systems") OR (MH "Radiology Information Systems") OR (MH } \\
\text { "Decision Support Systems, Clinical") OR digital OR computerised } \\
\text { OR computerized OR EMR OR "electronic medical record*" OR } \\
\text { "electronic health record*" OR "mobile app" OR "mobile apps" OR } \\
\text { "mobile device*" OR PDA OR ipad }\end{array}$ \\
\hline perception* OR view* OR experience* OR opinion* OR feeling* & \\
\hline
\end{tabular}


Table 2 Data Extracted from the reviewed studies

\begin{tabular}{|c|c|c|c|c|c|c|}
\hline Author(s) & Year/Country & Sample & Aims & Study design & Key findings & Quality review \\
\hline $\begin{array}{l}\text { Alegría, } \\
\text { Boscardin, } \\
\text { Poncelet, } \\
\text { Mayfield, \& } \\
\text { Wamsley }\end{array}$ & 2014/USA & $\begin{array}{l}\text { Third-year } \\
\text { medical } \\
\text { students } \\
(n=15)\end{array}$ & $\begin{array}{l}\text { To describe how } \\
\text { students in a } \\
\text { longitudinal integrated } \\
\text { clerkship using tablet } \\
\text { computers for self- } \\
\text { regulated learning. }\end{array}$ & $\begin{array}{l}\text { Qualitative: } \\
\text { Focus groups }\end{array}$ & $\begin{array}{l}\text { Tablet computers promote self-regulated } \\
\text { student learning in placements. Students } \\
\text { were able to access electronic health records } \\
\text { (EHRs) using the tablet computers but they } \\
\text { did not do so during consultations. Students } \\
\text { perceived more value in using the tablet } \\
\text { computers as an educational tool than as a } \\
\text { clinical tool. }\end{array}$ & Medium \\
\hline $\begin{array}{l}\text { Baillie, } \\
\text { Chadwick, } \\
\text { Mann, \& } \\
\text { Brooke-Read }\end{array}$ & 2013/UK & $\begin{array}{l}\text { Nursing } \\
\text { and } \\
\text { midwifery } \\
\text { students } \\
\text { survey } \\
\text { ( } n=215 \text { ); } \\
\text { focus } \\
\text { groups } \\
\text { ( } n=17 \text { ) }\end{array}$ & $\begin{array}{l}\text { To investigate the } \\
\text { experience of student } \\
\text { nurses and midwives in } \\
\text { learning to use EHRs in } \\
\text { practice. }\end{array}$ & $\begin{array}{l}\text { Mixed-methods: } \\
\text { Quantitative: } \\
\text { Questionnaire } \\
\text { Qualitative: } \\
\text { Focus groups }\end{array}$ & $\begin{array}{l}\text { Students had variable experiences accessing } \\
\text { and using EHRs in practice: } 61 \% \text { response rate } \\
\text { of the survey: only } 58 \% \text { felt prepared for } \\
\text { using EHRs and } 41 \% \text { could only access EHRs } \\
\text { under direct supervision; } 28 \% \text { were denied } \\
\text { access at ward or organisational level. }\end{array}$ & $\begin{array}{l}\text { Moderate. Although this } \\
\text { study employed a mixed- } \\
\text { methods approach, the } \\
\text { paper presented } \\
\text { insufficient explanations } \\
\text { of data analysis and how } \\
\text { results were integrated. } \\
\text { For example, focus group } \\
\text { data only used to confirm } \\
\text { survey findings. }\end{array}$ \\
\hline $\begin{array}{l}\text { Brooke- } \\
\text { Read, Baillie, } \\
\text { Mann, \& } \\
\text { Chadwick }\end{array}$ & 2012/UK & $\begin{array}{l}\text { Midwifery } \\
\text { students } \\
(n=28)\end{array}$ & $\begin{array}{l}\text { To investigate the } \\
\text { experience of midwifery } \\
\text { students of using EHRs in } \\
\text { practice. }\end{array}$ & $\begin{array}{l}\text { Mixed-methods: } \\
\text { Quantitative: } \\
\text { A questionnaire } \\
\text { was developed } \\
\text { for this study } \\
\text { from literature } \\
\text { review } \\
\text { Qualitative: } \\
\text { Focus groups }\end{array}$ & $\begin{array}{l}\text { Not all students had access to EHRs. Most } \\
\text { students only accessed EHRs for admission } \\
\text { information ( } n=8 ; 29 \% \text { ) or discharge } \\
\text { information ( } n=12 ; 43 \%) \text {, Themes from focus } \\
\text { groups: Benefits of EHRs for care delivery; } \\
\text { practical issues of EHRs and accountability; } \\
\text { incongruence between EHRs and the concept } \\
\text { of 'normality'. }\end{array}$ & Low quality \\
\hline
\end{tabular}




\begin{tabular}{|c|c|c|c|c|c|c|}
\hline Author(s) & Year/Country & Sample & Aims & Study design & Key findings & Quality review \\
\hline $\begin{array}{l}\text { Davies, } \\
\text { Rafique, } \\
\text { Vincent, } \\
\text { Fairclough, } \\
\text { Packer, } \\
\text { Vincent, \& } \\
\text { Haq }\end{array}$ & 2012/UK & $\begin{array}{l}\text { Medical } \\
\text { students } \\
(n=387)\end{array}$ & $\begin{array}{l}\text { To investigate how the } \\
\text { medical students used } \\
\text { mobile technology and } \\
\text { how it enabled them to } \\
\text { learn, what learning } \\
\text { theories contributed, } \\
\text { what barriers were } \\
\text { encountered and what } \\
\text { could be done to } \\
\text { overcome them. }\end{array}$ & $\begin{array}{l}\text { Mixed-methods: } \\
\text { Quantitative: } \\
\text { Pre/post survey } \\
\text { and usage } \\
\text { tracking data } \\
\text { Qualitative: } \\
\text { Focus groups }\end{array}$ & $\begin{array}{l}\text { Use of PDA as an addition to learning ecology, } \\
\text { rather than a replacement. Student learning } \\
\text { was enabled by providing timely access to } \\
\text { facts when undertaking patient consultations. } \\
\text { A conceptual model was developed for } \\
\text { technology use in medical education. }\end{array}$ & $\begin{array}{l}\text { High quality. A large } \\
\text { cohort for survey and use } \\
\text { of an appropriate } \\
\text { qualitative theory for } \\
\text { data analysis, that is, } \\
\text { using grounded theory to } \\
\text { develop a model of } \\
\text { mobile learning in clinical } \\
\text { settings. }\end{array}$ \\
\hline $\begin{array}{l}\text { Johansson, } \\
\text { Petersson, \& } \\
\text { Nilsson }\end{array}$ & 2013/Sweden & $\begin{array}{l}\text { Nursing } \\
\text { students } \\
\text { ( } \mathrm{n}=67 ; \\
\text { randomly } \\
\text { selected) }\end{array}$ & $\begin{array}{l}\text { To explore the } \\
\text { experience of nursing } \\
\text { students in using a PDA } \\
\text { in practice. }\end{array}$ & $\begin{array}{l}\text { Mixed-methods: } \\
\text { Quantitative: } \\
\text { Pre/post } \\
\text { questionnaire } \\
\text { Qualitative: } \\
\text { Focus groups }\end{array}$ & $\begin{array}{l}\text { PDA was useful to nursing students (more } \\
\text { efficient and safer). It also facilitated the } \\
\text { provision of improved quality of care for } \\
\text { patients and at their bedside. However, it is } \\
\text { not so easy to find resources online and the } \\
\text { quality of the resources varied. } \\
\text { The use of PDA also instilled confidence in } \\
\text { nursing students, although it would be more } \\
\text { useful if the PDA has more content and } \\
\text { functions in line with the Swedish nursing and } \\
\text { technical conditions. }\end{array}$ & $\begin{array}{l}\text { Moderate quality. A } \\
\text { mixed-methods study } \\
\text { using appropriate } \\
\text { qualitative theory for } \\
\text { data analysis. }\end{array}$ \\
\hline $\begin{array}{l}\text { Rouf, } \\
\text { Chumley, \& } \\
\text { Dobbie }\end{array}$ & 2008/USA & $\begin{array}{l}33 \\
\text { completed } \\
\text { question- } \\
\text { naires } \\
\text { from third- } \\
\text { year } \\
\text { medical } \\
\text { students }\end{array}$ & $\begin{array}{l}\text { To report the attitudes } \\
\text { of third-year medical } \\
\text { students towards clinical } \\
\text { learning using the EHRs } \\
\text { in two university-based } \\
\text { ambulatory primary care } \\
\text { clinics. }\end{array}$ & $\begin{array}{l}\text { Mixed-methods: } \\
\text { Focus group to } \\
\text { inform themes } \\
\text { for the } \\
\text { development of } \\
\text { the online } \\
\text { questionnaire }\end{array}$ & $\begin{array}{l}\text { Students considered EHRs as an } \\
\text { organisational and documentation tool. } \\
\text { Therefore, they underused the technical } \\
\text { features e.g. check medical interactions } \\
\text { offered by EHRs. } \\
\text { Students reported that they received more } \\
\text { feedback from educators on their EHR notes } \\
\text { compared to paper chart notes. However, } \\
\text { they were concerned about clinician/patient } \\
\text { interactions while using EHRs. }\end{array}$ & $\begin{array}{l}\text { Low quality. The paper } \\
\text { did not report qualitative } \\
\text { findings which were the } \\
\text { basis of developing the } \\
\text { online questionnaire. }\end{array}$ \\
\hline
\end{tabular}




\begin{tabular}{|c|c|c|c|c|c|c|}
\hline Author(s) & Year/Country & Sample & Aims & Study design & Key findings & Quality review \\
\hline $\begin{array}{l}\text { Wack, } \\
\text { Puymirat, } \\
\text { Ranque, } \\
\text { Georgin- } \\
\text { Lavialle, } \\
\text { Pierre, } \\
\text { Tanguy, } \\
\text { Ackermann, } \\
\text { Mallet, } \\
\text { Pavie, } \\
\text { Boultache, } \\
\text { Durieux, \& } \\
\text { Avillach }\end{array}$ & 2015/France & $\begin{array}{l}\text { Medical } \\
\text { students: } \\
\text { Total: } 35 \\
\text { students } \\
1^{\text {st }} \text { quarter: } \\
18 \\
2^{\text {nd }} \\
\text { quarter: } 17 \\
\text { The same } \\
7 \text { Chief } \\
\text { Residents } \\
\text { in both } \\
\text { quarters. }\end{array}$ & $\begin{array}{l}\text { To evaluate the impact } \\
\text { of computerised } \\
\text { provider order entry } \\
\text { (CPOE) at the bedside on } \\
\text { training of medical } \\
\text { students. }\end{array}$ & $\begin{array}{l}\text { A randomised } \\
\text { controlled trial } \\
\text { (RCT): } \\
\text { one group using } \\
\text { CPOE bedside } \\
\text { ordering as part } \\
\text { of the teaching } \\
\text { round and the } \\
\text { other group did } \\
\text { not use CPOE } \\
\text { and the bedside } \\
\text { teaching was } \\
\text { conducted as } \\
\text { usual. } \\
\text { Questionnaires } \\
\text { for medical } \\
\text { students: at } \\
\text { beginning and } \\
\text { end of trial. } \\
\text { Also, } \\
\text { satisfaction } \\
\text { questionnaire } \\
\text { completed at } \\
\text { the end of the } \\
\text { rotation. }\end{array}$ & $\begin{array}{l}\text { No significant difference in prescription skills } \\
\text { between two groups. However, the group } \\
\text { using CPOE bedside ordering indicated a } \\
\text { greater student satisfaction, feeling of } \\
\text { commitment to the patients' care and their } \\
\text { sense of belonging to the medical team. }\end{array}$ & Moderate quality RCT \\
\hline
\end{tabular}

